\section{Intra and postoperative effectives of oral transmucosal administration of phenylbutazone for pain managament in dogs}

\section{Köpeklerde fenilbutazon oral transmukozal uygulamasının operasyon sırası ve sonrasında ağrı yönetimindeki etkileri}

\section{ABSTRACT}

The aim of the present study was to evaluate the efficacy and analgesic duration of single dose of phenylbutazone administered by oral transmucosal route immediately before induction of anesthesia in dogs undergoing elective ovariohysterectomy. Eight-teen sexually intact female dogs (weighing between 5 and $30 \mathrm{~kg}$, and 1 to $7 \mathrm{yrs}$ of age) referred for ovariohysterectomy procedure from a local shelter at regular intervals over 3 months was included in the study. The dogs were administered phenylbutazone on the basis of their respective treatment group $(20 \mathrm{mg} / \mathrm{kg}$ via oral transmucosal administration) immediately before anesthetic induction. The syringe was placed in the cheek pouch of the dog, and phenylbutazone was slowly administered over a period of 1 to 3 minutes to ensure the drug did not drop out of the dog's mouth, or was not swallowed by the dog. In control group, $0.9 \% \mathrm{NaCl}$ was administered in the cheek pouch of the dog. Throughout the study, pre and postoperative pain was assessed at baseline (before induction of anesthesia) and then at 0.5, 1, 2, 3, 8 , and $24 \mathrm{hrs}$ after the surgery. Group oral transmucosal had significantly lower Glascow pain scores than the control group at the $0.5,1,2,3$, and 8 hour postoperative periods. In conclusion, a single dose of phenylbutazone administered via the oral transmucosal route before surgery may be particularly beneficial for achieving reasonable perioperative analgesia, but not in postoperative period."

Keywords: Ovariohysterectomy, Pain, Phenylbutazone, Transmucosal

\section{ÖZET}

$\mathrm{Bu}$ çalışmanın amacı planlı overiyohisterektomi yapılan köpeklerde post operatif ağrı yönetiminde tek ilaç olarak verilen fenilbutazonun oral transmukozal verildiğindeki etkinliğini ve ağrı kesici etki süresini değerlendirmektir. Çalışmaya, yerel hayvan barınaklarından kliniğimize 3 ay boyunca ovariyohisterektomi amacıyla getirilen 18 erişkin dişi köpek (ağırlıkları 5 ve $30 \mathrm{~kg}$; yaşları 1-7 arasında) dâhil edildi. Köpeklere çalışma gruplarında $20 \mathrm{mg} / \mathrm{kg}$ dozda oral transmukozal fenilbutazon hemen operasyon öncesinde verildi. Enjektör iğnesi köpeğin yanak mukozasına yerleştirildi, 1-3 dk arasında ağız boşluğuna damlamayacak ve şişkinlik olmayacak şekilde yavaşça verildi. Kontrol grubunda \%0,9'luk $\mathrm{NaCl}$ köpeklerin yanak mukozasına uygulandı. Çalışma süresince operasyon öncesi ve sonrası ağr1; başlarken (anestezi uygulaması öncesinde), sonrasında $0.5,1,2,3,8$ ve 24 . saatlerde değerlendirildi. Oral transmukozal grubunda Glaskov ağrı değerlendirme skorları, operasyon sonras 1 0.5, 1, 2, 3 ve 8 . saatlerde kontrol grubundan istatistiki olarak düşük değerlerdeydi. Sonuç olarak, operasyon öncesinde oral transmukozal yol ile verilen tek doz fenilbutazon intraoperativ kabul edilebilir analjezi sağlayabilir ama operasyon sonrasında ağrının kontrolünde yetersizdir.

Anahtar Kelimeler: Ağrı, Fenilbutazon, Ovariyohisterektomi, Transmukozal

\section{How to cite this article}

Kibar, M. (2019). Intra and postoperative effectives of oral transmucosal administration of phenylbutazone for pain management in dogs. J Adv VetBio Sci Tech, 4(3), 90-97. https://doi.org/10.31797/vetbio.613155
Research Article

\section{Murat Kibar}

Artvin University, Artvin Vocational School, Department of Forestry, Hunting and Wild Life Programme, Artvin 08100, Turkey. ORCIID - 0000-0001-8879-4121

\section{Correspondence}

Artvin University, Seyitler Campus, Artvin 08100, Turkey. muratkibartr@yahoo.com

Phone: +904662151000

Article info

Submission: 01-08-2019

Accepted: 06-12-2019

Online first published: 23-12-2019

Published: 30-12-2019

This work is licensed under a Creative Commons Attribution 4.0 International License 


\section{T}

\section{NTRODUCTION}

Phenylbutazone (PBZ) is a potent nonsteroidal anti-inflammatory drug, first introduced in 1952 for the treatment of arthritis. Phenylbutazone has been shown to be effective in managing pain associated with a variety of companion animal diseases (Williamson et al., 1978; Mbugua et al., 1989; Zech et al., 1993; Mills et al., 1995).

Administration of analgesics via the oral transmucosal (OTM) route provides several potential advantages over parenteral administration (Ko et al., 2011). The various routes of administration for PBZ is commonly used in animals (Mbugua et al., 1989; Zech et al., 1993; Mills et al., 1995), but OTM route has not been used extensively in dogs because of a lack of pharmacodynamic data supporting such use.

To determine the dose and efficacy for OTM administration of analgesics in dogs, pharmacokinetic studies (Williamson et al., 1978; Mbugua et al., 1989; Zech et al., 1993) were performed to compare the bioavailability, dosage, and dosing interval for administration via the OTM route. The clinical importance of the OTM route of PBZ for the management of postoperative pain in dogs is unknown. Furthermore, there is no available data about the therapeutic and adverse effects in dogs. Although previously investigated for pain relief of musculoskeletal problems (Mbugua et al., 1989), OTM route administration of PBZ have not been evaluated for postoperative pain relief in animals undergoing elective surgery. As ovariohysterectomy $(\mathrm{OVH})$ procedure is the most common type of clinical case referred to veterinary clinics, the present study includes this type of procedure so that the results may be of use to small animal practitioners. We hypothesized that the PBZ administered via the OTM route would be effective in providing preoperative and postoperative analgesia in dogs.

The aim of the present study was to evaluate the efficacy and analgesic duration of single dose of PBZ administered by OTM route immediately before induction of anesthesia in dogs undergoing elective $\mathrm{OVH}$.

\section{MATERIALS AND METHODS}

Ethical Scope: The study protocol was approved by the local ethics committee (approval number: 2014-12). The study was carried out at the place where Ethical approval was obtained.

A randomized, double-blinded study was conducted. Eight-teen sexually intact female dogs referred for $\mathrm{OVH}$ procedure from a local shelter at regular intervals over 3 months were included in the study. Before final enrolment the dogs had to fulfill a set of predetermined inclusion and exclusion criteria (Table 1). All dogs were discharged 24 hours after surgery. Heparinized blood samples $(4 \mathrm{ml})$ were collected through the indwelling cephalic vein catheter

\begin{tabular}{|l|}
\hline Body weight $\geq 5 \mathrm{~kg}$ \\
\hline Age $\geq 1$ year \\
\hline No previous enrolment in this study \\
$\begin{array}{l}\text { Not too aggressive to safely enable postoperative } \\
\text { examinatio and/or pain scoring. }\end{array}$ \\
$\begin{array}{l}\text { No administration of non-steroidal anti- } \\
\text { inflammatory drugs epidural analgesia, or } \\
\text { local/regional analgesia within } 12 \text { hours prior to the } \\
\text { study }\end{array}$ \\
Not pregnant or lactating \\
No evidence or history of pre-existing heart disease \\
or clinically significant arrhythmia \\
No clinically significant hypotension \\
No evidence or a history of liver disease \\
\hline
\end{tabular}


The dogs were randomly allocated to one of two groups with nine dogs in each group. The dogs were administered PBZ on the basis of their respective treatment group (20 $\mathrm{mg} / \mathrm{kg}$ via OTM administration) before administration of xylazine. For OTM administration, PBZ was diluted with equivalent $0.9 \% \mathrm{NaCl}$. The syringe was placed in the cheek pouch of the dog, and PBZ was slowly administered over a period of 1 to 3 minutes to ensure the drug did not drop out of the dog's mouth, or was not swallowed by the dog. Time of completion of PBZ administration was designed as time 0 . In control group, $0.9 \% \mathrm{NaCl}$ was administered in the cheek pouch of the dog.

Immediately after PBZ administration, the same anesthetic protocol was used for two groups. Dogs were premedicated xylazine (2 $\mathrm{mg} / \mathrm{kg}$ IM) (Alfazine ${ }^{\circledR}$, Egevet, Turkey). Fifteen minutes after premedication, general anesthesia was induced with ketamine (10 $\mathrm{mg} / \mathrm{kg}$ IM) (Alfamine ${ }^{\circledR}$, Egevet, Turkey). The right or left cephalic vein was cannulated using a 20 or $22 \mathrm{G}$ (Bıçakçılar, Turkey) over the needle catheter for the subsequent blood sampling. Electrocardiogram, non-invasive blood pressure, respiratory rate, heart rate, pulse oximetry, and rectal temperature were monitored (Guoteng Co Ltd, China) continuously throughout the anesthesia. A software application was used for data collection starting before the first incision and then every $5 \mathrm{~min}$ until the end of the OVH procedure.

Dogs were placed in the Trendelenburg position ( $15^{\circ}$ head down) to facilitate cranial displacement of the visceral contents of the abdominal cavity. Age, American Society of Anesthesiologist's physical status, duration of anesthesia (from injection of xylazine to final suture) and duration of operation (from the first skin incision to the final skin suture) were recorded for each dog. Ovary ligation procedure was in $\mathrm{T} 2$ time point.

Throughout the study, pre and postoperative pain was assessed at baseline (before induction of anesthesia) and then at $0.5,1,2,3,8$, and $24 \mathrm{hrs}$ after operation. The same researcher, who was unaware of each dog's group assignment, evaluated pain behaviors in all dogs using the short form of the Glosgow composite measures pain scale (CMPS-SF) (Reid et al., 2007). A total pain score ranging from 0 to 24 was calculated for each time point. After measuring postoperative pain behaviors at each time point, the researcher submitted the score sheet to the test leader who then calculated the scores. To control the severity of postoperative pain, if a dog was scored CMPS-SF > 6, IV carprofen $(4.4 \mathrm{mg} / \mathrm{kg}$ ) was to be given as a rescue analgesic. With the exception of subjects receiving penicillin + streptomycin $(0.1 \mathrm{ml} / \mathrm{kg}, \mathrm{IM})$, all drugs were received as a single dose.

Blood samples tested for plasma glucose were centrifuged at $1500 \mathrm{~g}$ for 10 minutes at room temperature. The plasma was removed and the blood samples were stored at $-80{ }^{\circ} \mathrm{C}$ in Eppendorf tubes. At the end of the study they were analyzed for glucose concentration by a commercial laboratory using a BA-88A Semi-Auto Chemistry Analyzer (Mindray, China).

Statistical Analyses: The SPSS software program (Version 12.0, SPSS Inc., Chicago, IL, USA) was used for statistical analysis. Shapiro-Wilks-W test, which one of normality tests, was used to determine whether the data were distributed normally before the variance analysis. ANOVA test was used to assess the differences between the groups. When the interaction was statistically significant $(\mathrm{p}<0.05)$, Tukey's test 
was used for binary comparisons between groups and homogeneous groups were formed.

\section{RESULTS}

The dogs were between 5 and $30 \mathrm{~kg}$, and 1 to $7 \mathrm{yrs}$ of age. Subjects from the two groups were similar in age $(3.0 \pm 1.2$ years in group OTM and $2.63 \pm 1.8$ years in the control group) and body weight (group OTM, 15.38 $\pm 6.3 \mathrm{~kg}$ and control group, $15.88 \pm 7.80 \mathrm{~kg}$ ) and there was no difference in age and body weight between the groups. The duration of surgery was 20-42 min. All dogs were classified as having ASA physical status I. During the study, the stages of the sexual cycle in dogs were determined as follows: 12 dogs were in anoestrus, $3 \mathrm{dog}$ were in dioestrus, and 1 dog were in metoestrus. In addition, one dog was pseudopregnant, and one dog was propubertas.

There were no significant differences between the experimental groups taking intraoperative monitoring values (mean \pm $\mathrm{SD})$. All of these values were within the respective reference ranges for anesthetized dogs (Pacheco et al., 2018) (Table 2). Mean $( \pm \mathrm{SD})$ diastolic and mean blood pressure (BP) values increased $20 \%$ in the control group following the ligation procedure (Table 2, T2 time point). No data increase was observed in the OTM group following the ligation procedure. All of the dogs recovered from the anesthesia normally and without complications.

Table 2. Distribution of intraoperative vital functions in dogs (Mean \pm SD)

\begin{tabular}{|c|c|c|c|c|c|c|c|}
\hline \multirow{2}{*}{$\begin{array}{l}\text { Parameters / } \\
\text { Group }\end{array}$} & \multicolumn{7}{|c|}{ Intraoperative Times } \\
\hline & $\begin{array}{c}\text { T0 } \\
(0 \mathrm{~min})\end{array}$ & $\begin{array}{c}\mathrm{T} 1 \\
(5 \mathrm{~min})\end{array}$ & $\begin{array}{c}\mathrm{T} 2 \\
(10 \mathrm{~min})\end{array}$ & $\begin{array}{c}\mathrm{T} 3 \\
\text { (15 min) }\end{array}$ & $\begin{array}{c}\mathrm{T} 4 \\
(20 \mathrm{~min})\end{array}$ & $\begin{array}{c}\mathrm{T} 5 \\
(25 \mathrm{~min})\end{array}$ & $\begin{array}{c}\text { T6 } \\
(30 \mathrm{~min})\end{array}$ \\
\hline \multicolumn{8}{|l|}{$\mathrm{SpO}_{2}$} \\
\hline Control & $94.86 \pm 5.97$ & $88.71 \pm 8.76$ & $89.86 \pm 6.84$ & $90.71 \pm 4.80$ & $91.86 \pm 5.76$ & $91.00 \pm 6.75$ & $91.50 \pm 3.24$ \\
\hline ОТМ & $92.11 \pm 6.06$ & $91.00 \pm 5.76$ & $90.00 \pm 5.73$ & $91.11 \pm 4.74$ & $92.00 \pm 4.32$ & $90.25 \pm 5.01$ & $91.00 \pm 9.63$ \\
\hline \multicolumn{8}{|c|}{ Respiratory Rate } \\
\hline Control & $11.86 \pm 3.03$ & $13.40 \pm 5.55$ & $14.50 \pm 2.79$ & $12.71 \pm 1.83$ & $12.86 \pm 5.43$ & $12.17 \pm 3.57$ & $12.71 \pm 2.43$ \\
\hline OTM & $11.50 \pm 2.01$ & $12.90 \pm 3.00$ & $13.43 \pm 2.28$ & $12.11 \pm 1.77$ & $12.78 \pm 4.08$ & $12.63 \pm 3.24$ & $12.67 \pm 1.65$ \\
\hline \multicolumn{8}{|l|}{ Heart Rate } \\
\hline Control & $80.00 \pm 36.15$ & $88.88 \pm 31.50$ & $98.57 \pm 43.56$ & $87.00 \pm 21.81$ & $80.43 \pm 27.81$ & $78.71 \pm 19.17$ & $78.00 \pm 39.96$ \\
\hline OTM & $80.89 \pm 24.09$ & $91.38 \pm 29.40$ & $97.33 \pm 34.77$ & $86.67 \pm 18.27$ & $79.33 \pm 20.67$ & $77.11 \pm 14.97$ & $75.75 \pm 22.41$ \\
\hline \multicolumn{8}{|c|}{ BP(systolic) } \\
\hline Control & $130.33 \pm 29.94$ & $150.13 \pm 27.27$ & $7168.88 \pm 30.99$ & $9158.25 \pm 29.5$ & $2147.25 \pm 24.75$ & $5141.45 \pm 26.04$ & $4134.63 \pm 27.18$ \\
\hline OTM & $132.23 \pm 27.60$ & $143.50 \pm 28.68$ & $8150.60 \pm 22.05$ & $5140.33 \pm 25.5$ & $3132.23 \pm 23.97$ & $7124.93 \pm 28.71$ & $1121.75 \pm 22.86$ \\
\hline \multicolumn{8}{|l|}{ BP (mean) } \\
\hline Control & $110.13 \pm 19.32$ & $135.54 \pm 26.94$ & $144.25 \pm 32.40$ & $0134.63 \pm 30.18$ & $8126.38 \pm 25.14$ & $4123.43 \pm 23.94$ & $4118.54 \pm 29.34$ \\
\hline OTM & $109.75 \pm 27.00$ & $119.93 \pm 26.61$ & $127.63 \pm 28.98$ & $8108.50 \pm 22.5$ & $9106.50 \pm 20.16$ & $6105.77 \pm 23.31$ & $1110.52 \pm 25.95$ \\
\hline \multicolumn{8}{|c|}{ BP (diastolic) } \\
\hline Control & $99.00 \pm 23.64$ & $120.25 \pm 22.6$ & $125.52 \pm 23.34$ & $4118.87 \pm 21.9$ & $6110.50 \pm 17.70$ & $0106.00 \pm 17.43$ & $3102.50 \pm 28.65$ \\
\hline OTM & $94.25 \pm 27.78$ & $92.25 \pm 25.02$ & $96.50 \pm 28.53$ & $98.50 \pm 26.01$ & $96.75 \pm 18.78$ & $8 \quad 98.29 \pm 23.19$ & $95.69 \pm 14.97$ \\
\hline
\end{tabular}


In the preoperative period, all animals had a CMPS-SF score of 0. Group OTM had significantly lower CMPS-SF scores $(\mathrm{P}<0.05)$ than the control group at the $0.5,1$, 2,3 , and 8 hours postoperatively (Table 3 ). The highest and lowest CMPS-SF values were determined at $0.5 \mathrm{~h}(9.44 \pm 1.32)$ and $24 \mathrm{~h}$ after surgery $(6.44 \pm 1.80)$ in group OTM. Likewise, the highest and lowest CMPS-SF values were determined at $0.5 \mathrm{hr}$. (11.71 \pm 0.54$)$ and $24 \mathrm{hr}$. after surgery (7.29 \pm 1.44 ) in the control group. The CMPS-SF scores were $>6$ in all dogs at different periods in the groups. The rescue analgesic (carprofen) was used with all dogs.

Table 4 demonstrates the mean $( \pm$ SD) plasma glucose levels at each time point. Glucose concentration spiked at $3 \mathrm{hrs}$. in all groups. Glucose levels differed significantly at 3 and 8 hours for group OTM when measured against the control group $(\mathrm{P}<0.05)$. Glucose concentration decreased quicker in groups OTM than in the control group. Only the values at 3 and 8 hours after the surgery were significantly $(\mathrm{P}<0.05)$ higher than the baseline value in the control group.

Table 3. Mean CMPS-SF scores from each groups of dogs at each time point

\begin{tabular}{|lcccccc|}
\hline & \multicolumn{5}{c}{ Postoperative } \\
Groups & $\mathbf{0 . 5 h}$ & $\mathbf{1 h}$ & $\mathbf{2 h}$ & $\mathbf{3 h}$ & $\mathbf{8 h}$ & $\mathbf{2 4 h}$ \\
\hline Control & $11.71 \pm 0.54^{\mathrm{aA}}$ & $10.57 \pm 1.11^{\mathrm{aA}}$ & $10.29 \pm 1.41^{\mathrm{aA}}$ & $9.57 \pm 1.29^{\mathrm{bA}}$ & $9.29 \pm 1.08^{\mathrm{bA}}$ & $7.29 \pm 1.44^{\mathrm{bA}}$ \\
OTM & $9.44 \pm 1.32^{\mathrm{aB}}$ & $8.89 \pm 0.78^{\mathrm{aB}}$ & $8.22 \pm 0.66^{\mathrm{aB}}$ & $6.89 \pm 1.77^{\mathrm{bB}}$ & $6.78 \pm 1.86^{\mathrm{bB}}$ & $6.44 \pm 1.80^{\mathrm{bA}}$ \\
\hline
\end{tabular}

OTM: Oral transmucosal. ${ }^{a b c}$ means with different superscripts within one row differ significantly $(\mathrm{p}<0.05)$. ${ }^{\mathrm{ABC}}$ Different letters in the column indicate the significant differences $(\mathrm{p}<0.05)$.

Table 4. Plasma glucose levels (means \pm SD) taken from dogs treated with phenylbutazone given OTM and control group

\begin{tabular}{|lcccc|}
\hline Groups & $\begin{array}{c}\text { Before operation } \\
(\mathbf{0} \text { h })\end{array}$ & $\mathbf{3 h}$ & $\begin{array}{c}\text { After operation } \\
\mathbf{8 h}\end{array}$ & $\mathbf{2 4 h}^{\mathbf{3 h}}$ \\
\hline Control & $67.14 \pm 19.59^{\mathrm{aA}}$ & $211.86 \pm 57.42^{\mathrm{bA}}$ & $180.57 \pm 40.09^{\mathrm{bA}}$ & $89.14 \pm 33.83^{\mathrm{aA}}$ \\
OTM & $70.44 \pm 14.22^{\mathrm{A}}$ & $83.89 \pm 22.68^{\mathrm{B}}$ & $80.33 \pm 30.45^{\mathrm{B}}$ & $76.22 \pm 25.17^{\mathrm{A}}$ \\
\hline
\end{tabular}

OTM: Oral transmucosal. ${ }^{a b c}$ Means with different superscripts within one row differ significantly $(\mathrm{p}<0.05)$. ${ }^{A B C}$ Different letters in the column indicate the significant differences $(p<0.05)$.

\section{DISCUSSION}

Pharmacokinetic parameters for PBZ have been evaluated in several species (Lees et al., 2004). Dogs were selected in this study for several reasons: i) numerous formulations are available for use in this pet animal species, ii) administration of PBZ by OTM route had not been approved for postoperative analgesia in dogs.
It is reported that heart rate and blood pressure values are direct physiological indicators of intraoperative sympathetic reaction to nociceptive stimulation (Thurman et al., 1996; Ortega and Cruz 2011). In lambs, heart rate and blood pressure were demonstrated to be more accurate as signs of pain than cortisol or ACTH plasma measurements (Peers et al., 2002). Systolic, mean and diastolic blood pressure values, and respiratory rate increased $20 \%$ in the 
control group after ovarian ligation procedure. No value increased by that much in the OTM group. The parameters applied here showed that the intensity of pain had determinable physiologic impact on the animals as determined by a researcher. We are not aware of any published articles that evaluate the physiological effects of OTM administration of PBZ in dogs but, it was noted that these route were relatively reliable in normal dogs.

Many pain scaling systems, such as verbal rating scales, numeric rating scales, simple descriptive scales, and the visual analogue scale, are used to evaluate the degree of pain and stress in the postoperative period (Grandemange et al., 2013). Acknowledging that no scoring system is perfect, the Glasgow CMPS-SF (Reid et al., 2007) was chosen for evaluation of pain in this study. This scoring system has been seen to be a dependable clinical device for determining different pain severity as well as modifications in the degree of pain over time in a population of dogs undertaking a range of open surgeries (Reid et al., 2007). In the current study, the CMPS-SF points were significantly reduced in group OTM when compared to the control group throughout the monitoring period, except at $24 \mathrm{hrs}$. All times were showed values higher than 6 points. Use of only one researcher also restricted the variability in evaluating pain using the CMPS-SF.

Strength analysis was achieved before the beginning of the study based on the notion that a numerical distinction in a pain score of 3 using the CMPS-SF would be clinically suitable when contrasting postoperative analgesics (Hunt et al., 2013). This notion rests on previous studies investigating the CMPS-SF in a clinical setting (Hunt et al., 2013; Gruet et al., 2013) which found that a
95\% reliance interval for the difference in median pain value (dogs requiring analgesiano analgesia) was attained using 3-5 scores. In all dogs (OTM and control) CMPS-SF scores were higher than 6 and that all of them required rescue analgesia with carprofen. This means that PBZ was not effective enough to provide dogs with appropriate postoperative analgesia.

The significant limitations of the study are debated below. First, the researcher was to apply rescue analgesia at any time during the postoperative period if needed, and all dogs were provided with this therapy. All of the dogs with CMPS-SF scores above the thresholds given above is perhaps due to the fact that opioids were not applied in any dog. Successful control of pain after surgical procedure requires mixed therapy with opioids and nonsteroidal anti-inflammatory drugs (Hunt et al., 2013; Gruet et al., 2013). Second, the restrictions of non-inferiority research using positive controls are well known (Hunt et al., 2013; Gruet et al., 2013). In this case, use of a placebo would have advanced ethical and recruitment issues in this study as a number of anti-analgesics are recorded for intraoperative use in dogs and substantially used. Although it has been proposed that a placebo group should be contained to confirm the scoring system when controlling pain (Carpenter and Mcdonnel, 1995; Grandemange et al., 2013), there are considerable welfare concerns related to abnegating dogs' postoperative pain relief under clinical status. Third, use of $20 \mathrm{mg} \mathrm{PBZ} / \mathrm{kg}$ in clinical settings is now accessible as commercial brands of PBZ are present only at concentrations of $200 \mathrm{mg} / \mathrm{ml}$. Therefore, we diluted the PBZ with an equal volume of $0.9 \% \mathrm{NaCl}$ solution in order to avoid local irritation. There was no complication with application of PBZ. 
Fourth and last, we chose to administer PBZ at the same time point (immediately before the induction). Different Tmax after OTM administration is expected. This can be find out unreliable results especially when assessing intraoperative analgesia.

Serum glucose concentration was detected as the objective measure for understanding the biochemical stress response to open surgery. Serum glucose concentration is a useful evaluator of surgical stress, although quantifying glucose may not be an absolute means of determining surgical stress. Marcovich (Marcovich et al., 2001) researched the changes of serum glucose and cortisol levels $24 \mathrm{hrs}$ after different nephrectomy techniques in dogs. Serum glucose levels were significantly lower in OTM group when compared to the control group at the 3 and $8 \mathrm{hr}$ time points.

\section{CONCLUSION}

It was concluded that administered via the OTM route before OVH this is an effective analgesic with minimal intraoperative adverse effects. The OTM route provided intraoperatively acceptable analgesia. In conclusion, a single dose of PBZ administered via the OTM route before surgery may be particularly beneficial for achieving reasonable perioperative analgesia, but not in postoperative period.

\section{REFERENCES}

Carpenter, S.L., Mcdonnell, W.M. (1995). Misuse of veterinary phenylbutazone. Arch Intern Med, 155: 1229-1231.

Grandemange, E., Fournel, S., Woehrlé, F. (2013). Efficacy and safety of cimicoxib in the control of perioperative pain in dogs. $J$ Small Anim Pract, 54: 304-312.

Gruet, P., Seewald, W., King, N.J. (2013). Robenacoxib versus meloxicam for the management of pain and inflammation associated with soft tissue surgery in dogs: a randomized, non-inferiority clinical trial. BMC Vet Res, 9: 92.

Hunt, J.R., Grint, N.J., Taylor, P.M., et al. (2013). Sedative and analgesic effects of buprenorphine, combined with either acepromazine or dexmedetomidine, for premedication prior to elective surgery in cats and dogs. Vet Anaesth Analg, 40: 297-307.

Jackson, M.L., Searcy, G.P., Olexson, D.W. (1985). The effect of oral phenylbutazone on whole blood platelet aggregation in the dog. Can J Comp Med, 49: 271-277.

Ko, J.C., Freeman, L.J., Barletta, M., et al. (2011). Efficacy of oral transmucosal and intravenous administration of buprenorphine before surgery for postoperative analgesia in dogs undergoing ovariohysterectomy. $J \mathrm{Am}$ Vet Med Assoc, 238: 318-328.

Lees, P., Landoni, M.F., Giraudel, J., et al. (2004). Pharmacodynamics and pharmacokinetics of nonsteroidal antiinflammatory drugs in species of veterinary interest. J Vet Pharm Therap, 27: 479-490.

Marcovich, R., Williams, A.L., Seifman, B.D., et al. (2001). A canine model to assess the biochemical stress response to laparoscopic and open surgery. J Endourol, 15: 1005-1008.

Mbugua, S.W., Skoglund, L.A., Løkken, P. (1989). Effects of phenylbutazone and indomethacin on the post-operative course following experimental orthopaedic surgery in dogs. Acta Vet Scand, 30: 27-35.

Mills, P.C., Ng, J.C., Skelton, K.V., et al. (1995). Phenylbutazone in racing greyhounds: plasma and urinary residues 24 and 48 hours after a single intravenous administration. Aust Vet J, 72: 304-8.

Ortega, M. and Cruz, I. (2011). Evaluation of a constant rate infusion of lidocaine for balanced anesthesia in dogs undergoing surgery. Can Vet J, 52: 856-860.

Pacheco, P.F., Galeazzi, V.S., Patrício, G.C.F., et al. (2018). Anesthetic complications in diabetic dogs subjected to phacoemulsification. Pesq Vet Bras, 38: 1423-1430.

Peers, A., Mellor, D.J., Wintour, E.M., et al. (2002). Blood pressure, heart rate, hormonal 
and other acute responses to rubber-ring castration and tail docking of lambs. $N \mathrm{Z} \mathrm{Vet}$ J, 50: 56-62.

Reid, J., Nolan, A.M., Hughes, J.M.L., et al. (2007). Development of the short-form Glasgow Composite Measure Pain Scale (CMPS-SF) and derivation of an analgesic intervention score. Anim Welf, 16: 97-104.

Thurman, J.C., Tanquilli, W.J., Benson, G.J. (1996). Preanesthetics and anesthetic adjuncts. In: Thurmon JC, Tranquilli WC, Benson GJ eds. Lumb and Jones Veterinary Anesthesia. 3rd ed. Philadelphia: Williams and Wilkins, 183-203.

Williamson, H.E., Gaffney, G.R., Bourland, W.A., et al. (1978). Phenylbutazone-induced decrease in renal blood flow. J Pharmacol Exp Ther, 204: 130-134.

Zech, R., Scherkl, R., Hashem, A., Frey, H.H. (1993). Plasma and tissue kinetics of phenylbutazone and naproxen in dogs. Arch Int Pharmacodyn Ther, 325: 113-128 